\title{
Effective removal of the American bullfrog (Lithobates catesbeianus) on a landscape level: long term monitoring and removal efforts in Yosemite Valley, Yosemite National Park
}

\author{
Colleen Kamoroff $\mathbb{D} \cdot$ Ninette Daniele $\cdot$ Robert L. Grasso • Rebecca Rising • \\ Travis Espinoza $\cdot$ Caren S. Goldberg
}

Received: 7 March 2019/Accepted: 16 October 2019/Published online: 22 October 2019

(C) The Author(s) 2019

\begin{abstract}
Invasive alien species are a major threat to freshwater ecosystems, and American bullfrogs are among the world's 100 most prominent aquatic invasive species causing negative direct and indirect effect on native aquatic fauna worldwide. Bullfrogs were intentionally introduced into Yosemite Valley, Yosemite National Park in the 1950s where they became well established in the subsequent years. Starting in 2005, the National Park Service (NPS) began bullfrog removal, targeting various life stages using hand, net, and spear techniques. Starting in 2015, the NPS conducted environmental DNA (eDNA) surveys and deployed audio recordings devices to ensure adequate detection of bullfrogs. During the first year of cencerted effort in the Valley in 2005 , the NPS removed $86 \%$ of all recorded bullfrog.
\end{abstract}

C. Kamoroff $(\bowtie) \cdot$ N. Daniele · R. L. Grasso

Resource Management and Science, Yosemite National

Park, El Portal, CA 95318, USA

e-mail: colleen_kamoroff@nps.gov

R. Rising

North Cascades National Park, Sedro-Woolley,

WA 98284, USA

\section{T. Espinoza}

San Francisco Public Utility Commission, San Francisco, USA

C. S. Goldberg

School of the Environment, Washington State University, Pullman, WA 99164, USA
The subsequent decade was spent searching for individuals with lower return on effort. In 2012, the NPS removed the last observed signs of bullfrog breeding, and the last observed bullfrog in 2019 . Following removal of the breeding bullfrog population, the NPS began restoration projects for species of special concern. The NPS introduced the federally threatened California red-legged frogs (Rana draytonii) into Yosemite Valley beginning in 2016. This is the first published successful eradication of bullfrogs on a landscape level. National Parks and Monuments often provide refuges for imperiled wildlife and should be managed to remove invasive species. Our work highlights effective bullfrog removal is obtainable and can lead to local recovery of endangered species.

Keywords Alien invasive species - Aquatic restoration - California red-legged frog . Conservation · Environmental DNA · eDNA · Wildlife management

\section{Introduction}

Freshwater aquatic ecosystems are among the most imperiled ecological communities worldwide (Dudgeon et al. 2006). Invasive alien species are a major threat to freshwater ecosystems, and American bullfrogs (Lithobates (Rana) catesbeianus) are among the 
world's 100 most prominent aquatic invasive species (Lowe et al. 2000; Rahel et al. 2008; Bucciarelli et al. 2014). Bullfrogs, native only to eastern North America, occupy over 40 countries across 4 continents and Oceania (Adams and Pearl 2007). Human land-use changes, such as modifying aquatic habitats to support perennial water, helped facilitate the spread of invasive bullfrog populations (Ficetola et al. 2010; Fuller et al. 2011). Bullfrogs are incredibly fecund; females can lay multiple clutches of $>20,000$ eggs per season (Emlen 1977; Bury and Whelan 1985). As a result, bullfrogs become quickly established in new areas (Luja and Rodríguez-Estrella 2010; Orchard 2011). Bullfrog invasion has been linked to negative direct and indirect impacts on native species, including special status species, as well as lowering overall diversity and species richness in native amphibian communities through competition, predation and/or spreading parasites or diseases in areas around the globe (Moyle 1973; Kupferberg 1997; Adams and Pearl 2007; Bai et al. 2010; Schloegel et al. 2010; Da Silva et al. 2011; Li et al. 2011).

Bullfrogs were likely intentionally introduced into Yosemite National Park's valley in the 1950s. The first recorded observation of bullfrogs in Yosemite Valley was in 1955 at the Ahwahnee Hotel's reflection pond (Cunningham 1960). By the 1990s, bullfrog populations were well established throughout Yosemite Valley (Drost and Fellers 1996). Although Yosemite National Park is protected public land, it has experienced extirpations or declines of California red-legged frogs ( $R$. draytoni), Foothill yellow-legged frogs $(R$. boylii), Western toads (Anaxyrus (Bufo) boreas), Sierra newts (Taricha sierra), and Western pond turtles (Actinemys (Emys) marmorata) that are likely linked to the presence of invasive bullfrogs (Drost and Fellers 1996; Yosemite National Park unpublished data). In order to restore aquatic ecosystems, Yosemite National Park took management actions to remove all bullfrogs from Yosemite Valley.

\section{Methods}

Study area

Yosemite Valley (the Valley) is a glacially-carved valley on the western slope of the Sierra Nevada within Yosemite National Park (Fig. 1). The Valley elevation ranges from 900 to $1280 \mathrm{~m}$, spans across $\sim 1500$ ha, and contains the Merced Wild and Scenic River. The north and south sides of the Valley are bounded by steep granitic cliffs and the east and west sides of the valley are bounded by steep waterfalls or cascades. Yosemite Valley is a particularly good place for bullfrog eradication as bullfrogs do not inhabit the high elevation ( $>6000 \mathrm{ft}$.) aquatic tributaries that feed into the Merced River in the Valley. As a result, the only possible way for the non-assisted colonization of bullfrogs to the Valley would be from downstream source populations. The dramatic geological features of the Merced River canyon downstream from the Valley likely impede any natural migration of bullfrogs from neighboring populations.

The National Park Service (NPS) collected data on bullfrog removal efforts sporadically. The history of bullfrog removal in the Valley is a patchwork of raw data as well as anecdotal accounts (history of eradication effort in the Valley is summarized in Table 1). Bullfrog removal started opportunistically in the mid1990s by a single NPS employee who sporadically removed bullfrogs at breeding locations for less than a month a year until 2004. Bullfrog efforts began in earnest in the Valley in 2005 when the NPS hired 2 full time restoration technicians specifically for bullfrog removal. From 2005 to 2015 , a 1 or 2-person crew worked 1-4 mo./year surveying and removing bullfrogs throughout the Valley. During this time, the NPS collected data on the number of bullfrogs removed and did not record negative bullfrog sightings, the sex of bullfrogs removed, survey covariates, or the presence or densities of native anurans. After 2015, the NPS continued surveying for bullfrogs using traditional visual surveys as well as environmental DNA (eDNA) techniques. All bullfrog surveys and removal efforts occurred during the onset of breeding (mid-May) until the end of the summer (late August).

Removal techniques

To identify breeding bullfrog populations, the NPS conducted visual surveys for egg masses and larvae (tadpoles) around all available breeding habitat: slack water, ponds, or stagnant streams (Fig. 1). Bullfrog egg masses, which are formed as large gelatinous mats, are unlike native anuran egg masses of other species in Yosemite Valley, and therefore distinguishing species was possible via visual detection. Crews 


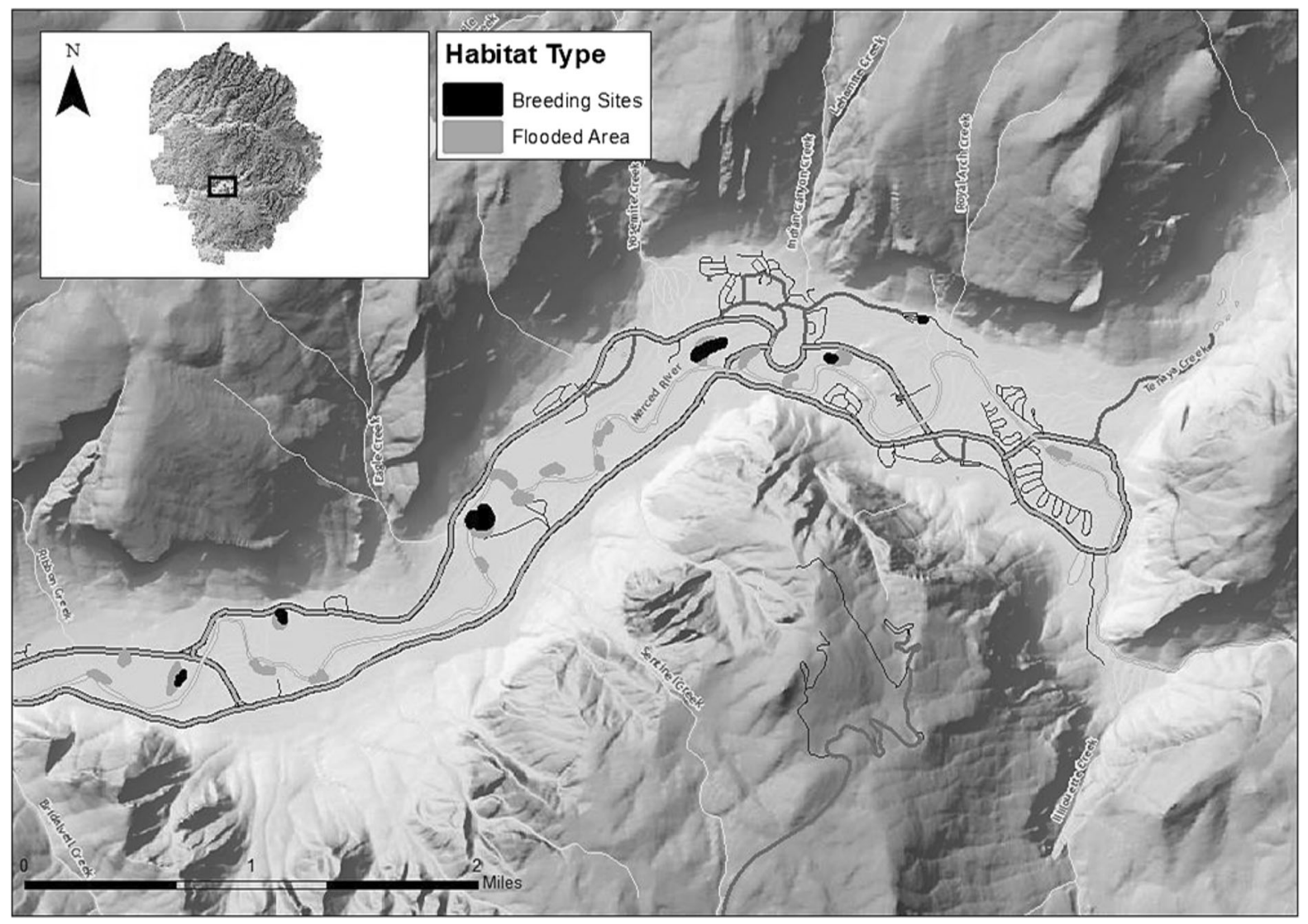

Fig. 1 Map of Yosemite Valley in Yosemite National Park, located in central California. The black breeding sites are areas where American bullfrog larvae and/or egg masses were

conducted breeding surveys in late spring and early summer (mid May to early June) during daylight hours (0900-1600 h; see Table 1 for yearly survey effort). During surveys, crews walked slowly through the water bodies removing any egg masses and larvae observed using dip nets, paint strainers, or 5-gallon buckets. Occasionally, crews would use a backpack electrofisher (Smith-Root, Vancouver, WA) or seine nets to remove larvae.

The NPS surveyed for and removed adult and subadult bullfrogs during night visual surveys from the onset of bullfrog breeding (May/June) until the end of summer (August/September; see Table 1 for yearly survey effort). Crews used 200+ lumen flashlights to locate and stupefy bullfrogs via eyeshine. Crews captured bullfrogs using a variety of methods: hand grabbing, spearing (trident pole spears outfitted with rubber sling), dip netting, seine netting, or shooting with pellet rifles. On occasion, crews caught frogs observed. The grey flooded areas are potential bullfrog habitat. Figure created in ArcMap

using hook and line methods. Crews also attempted to trap individuals using funnel traps with "Alive Lure $^{\mathrm{TM}}$,, a mechanical lure that looks and vibrates like an insect placed inside the traps as an attractant. (The funnel trap method was not successful in the Valley as no frogs were captured.)

The Ahwahnee Hotel reflection pond was an artificial concrete structure that sustained a breeding population of bullfrogs. Along with eradication activities stated above, in spring 2006, NPS drained the pond to remove all life stages of bullfrogs. This is the only water body that could be drained in the Valley. All other water bodies were naturally occurring.

We humanely euthanized all bullfrogs depending on life stage and capture method. Crews placed all collected egg masses on shorelines to dry. For adults and sub-adults captured via pole spear, crews would immediately euthanize the frog using skull blunt force trauma and pithing (Underwood et al. 2013). Crews 
Table 1 Survey and removal efforts of the American bullfrog (BF) in Yosemite Valley (the Valley) from 1990 to 2018

\begin{tabular}{|c|c|c|c|}
\hline Year & Description of staff ${ }^{a}$ & $\begin{array}{l}\text { Months/ } \\
\text { year }^{\text {b }}\end{array}$ & Description of activities ${ }^{c}$ \\
\hline $\begin{array}{l}\text { Mid } \\
1990 s- \\
2004\end{array}$ & $\begin{array}{l}1 \text { part time employee and } \\
\text { occasionally volunteers }\end{array}$ & $<1$ month & $\begin{array}{l}\text { Crews worked irregularly targeting and removing eggs and larvae at BF } \\
\text { breeding sites (Fig. 1), and opportunistically removed adults }\end{array}$ \\
\hline 2005-2006 & 2 full time employees & $\sim 4$ month & $\begin{array}{l}\text { Crews worked from onset of breeding season to the end of summer. } \\
\text { Crews targeted all life stages with particular attention to egg masse, } \\
\text { sub-adult, and adult BF. Crews removed the majority of BF during this } \\
\text { time }\end{array}$ \\
\hline 2007-2011 & $\begin{array}{l}1 \text { full time employee and } 1 \\
\text { volunteer }\end{array}$ & $<1$ month & $\begin{array}{l}\text { Crews surveyed and removed all life stages of BF for less than } 4 \text { weeks } \\
\text { per year }\end{array}$ \\
\hline 2012-2013 & 2 full time employees & $\sim 4$ months & $\begin{array}{l}\text { Crews worked from onset of breeding season through the summer. Crews } \\
\text { spent most of their time looking for BF (without many encounters), } \\
\text { including conducting transects for BF across the Valley }\end{array}$ \\
\hline 2014 & 2 part time employees & $\sim 4$ month & $\begin{array}{l}\text { Crews worked from onset of breeding season through the summer. Crews } \\
\text { spent most of their time surveying for BF (without many encounters). } \\
\text { Surveys included conducting transects through the Valley }\end{array}$ \\
\hline $2015-2016$ & 1 or 2 part time employees & $<1$ month & $\begin{array}{l}\text { Crews surveyed for bullfrogs at known bullfrog breeding location (Fig. 1) } \\
\text { and collected eDNA samples for } \sim 2-4 \text { weeks each year }\end{array}$ \\
\hline 2017 & - & - & No surveys or eDNA collected \\
\hline 2018 & 4-8 part time employees & $<1$ month & $\begin{array}{l}\text { Crews surveyed for bullfrogs at known bullfrog breeding location (Fig. 1) } \\
\text { and collected eDNA samples }\end{array}$ \\
\hline
\end{tabular}

${ }^{a}$ Number of individuals assigned to removal efforts and their work schedule (full time or part time)

${ }^{\mathrm{b}}$ Number of months surveying and removing BFs in the Valley

${ }^{\mathrm{c}}$ The area and life stages of focus during that time period

euthanized all other adult and sub-adult bullfrogs using a buffered solution of MS 2-22 at a concentration of 2-3 g/l solution at $\mathrm{pH} 7.0-7.5$ and/or skull blunt force and pithing protocol.

\section{Environmental DNA surveys and long term monitoring}

In 2015, Yosemite NPS began surveying for bullfrogs using aquatic eDNA sampling, an alternative survey technique sensitive to species at low densities. Species detection using eDNA methods is accomplished by collection and identification of trace DNA particles originating from shed skin cells, feces, etc., that are extracted from water samples (Taberlet et al. 2012). Environmental DNA methods have been used to detect aquatic amphibian species at low densities (Rees et al. 2014) and have been found to be more effective at detecting bullfrogs than traditional survey methods (Dejean et al. 2012; Goldberg et al. 2018).
For eDNA surveys, crews collected filtered water samples from suitable bullfrog habitats where breeding or presence was previously known (Fig. 1). The amount of water filtered as well as samples collected varied over the years as the NPS refined eDNA collection techniques. In 2015 and 2016, we collected a $50 \mathrm{ml}$ samples every $40 \mathrm{~m}$ around the perimeter or length of each site as this sampling strategy was proven effective for trout species (Kamoroff and Goldberg 2018; see also Dunker et al. 2016; Table 2). In 2018, we collected 250-500 ml water samples every $40 \mathrm{~m}$ around the perimeter or length of each site to attempt to collected 1-2 1 sample from each site (a standard eDNA sampling amount; Rees et al. 2014). However filter clogging and time limitation limited volume collected at some sites (Table 2). To detect any contamination from field equipment, we collected a $250-500 \mathrm{ml}$ field blank using distilled or deionized water per site or per sampling day. We filtered all water samples using a $0.45 \mu \mathrm{m}$ cellulose nitrate filter membrane with a $47 \mathrm{~mm}$ diameter filter funnel 
Table 2 Metadata for bullfrog environmental DNA (eDNA) sampling and visual survey sites in Yosemite Valley beginning in 2015

\begin{tabular}{|c|c|c|c|c|c|c|c|}
\hline $\begin{array}{l}\text { Site } \\
\text { type }^{\text {a }}\end{array}$ & Site name & $\begin{array}{l}\text { Survey } \\
\text { year }\end{array}$ & $\begin{array}{l}\text { Total amount filtered } \\
(\mathrm{ml})\end{array}$ & $\begin{array}{l}\text { \# eDNA } \\
\text { samples }\end{array}$ & $\begin{array}{l}\text { LICA DNA } \\
\text { detected }^{\mathrm{b}}\end{array}$ & $\begin{array}{l}\text { Total min. } \\
\text { surveyed }^{\mathrm{c}}\end{array}$ & $\begin{array}{l}\text { LICA } \\
\text { observed }\end{array}$ \\
\hline Breeding & $\begin{array}{l}\text { Awahnee } \\
\text { pond }\end{array}$ & 2015 & 500 & 2 & Yes & 8 & No \\
\hline Breeding & Camp 6 & 2015 & 200 & 3 & Yes & 338 & No \\
\hline Breeding & Cathedral east & 2015 & 200 & 2 & No & 814 & Yes \\
\hline Breeding & $\begin{array}{l}\text { Cooks } \\
\text { meadow }\end{array}$ & 2015 & - & - & - & 56 & No \\
\hline Breeding & $\begin{array}{l}\text { El Cap. } \\
\text { meadow }\end{array}$ & 2015 & - & - & - & 28 & No \\
\hline Breeding & V6 & 2015 & $>300$ & 7 & Yes & 98 & No \\
\hline Flooded & Waski & 2015 & - & - & - & 14 & No \\
\hline Breeding & $\begin{array}{l}\text { Awahnee } \\
\text { pond }\end{array}$ & 2016 & 750 & 3 & No & - & - \\
\hline Breeding & Camp 6 & 2016 & 1250 & 5 & No & - & - \\
\hline Breeding & Cathedral east & 2016 & $>500$ & 6 & No & 106 & No \\
\hline Breeding & $\begin{array}{l}\text { Cooks } \\
\text { meadow }\end{array}$ & 2016 & 750 & 3 & No & - & - \\
\hline Breeding & $\begin{array}{l}\text { El cap. } \\
\text { meadow }\end{array}$ & 2016 & NA & 3 & No & - & - \\
\hline Other & Merced river & 2016 & 750 & 3 & No & - & - \\
\hline Flooded & Mirror lake & 2016 & $>750$ & 5 & Yes & - & - \\
\hline Breeding & $\begin{array}{r}\text { Sentinel } \\
\text { bridge }\end{array}$ & 2016 & 1000 & 3 & No & - & - \\
\hline Breeding & V6 & 2016 & 1025 & 5 & Yes & 242 & No \\
\hline Flooded & Waski & 2016 & - & - & - & 165 & No \\
\hline Flooded & Yellow pine & 2017 & - & - & - & 165 & No \\
\hline Breeding & $\begin{array}{l}\text { Awahnee } \\
\text { pond }\end{array}$ & 2018 & 1200 & 4 & - & 66 & No \\
\hline Flooded & $\begin{array}{l}\text { Backpacker's } \\
\text { CG }\end{array}$ & 2018 & - & - & - & 604 & No \\
\hline Breeding & Camp 6 & 2018 & 650 & 4 & No & 192 & No \\
\hline Breeding & Cathedral east & 2018 & 1170 & 4 & Yes & 20 & No \\
\hline Breeding & $\begin{array}{l}\text { Cooks } \\
\text { meadow }\end{array}$ & 2018 & - & - & - & 574 & No \\
\hline Flooded & Mirror lake & 2018 & 1200 & 4 & No & 3303 & No \\
\hline Breeding & $\begin{array}{r}\text { Sentinel } \\
\text { bridge }\end{array}$ & 2018 & - & - & - & 50 & No \\
\hline Breeding & V6 & 2018 & 550 & 4 & No & - & - \\
\hline Flooded & Yellow pine & 2018 & 420 & 4 & No & 212 & No \\
\hline
\end{tabular}

${ }^{a}$ Breeding sites are areas where NPS observed bullfrogs breeding at some point during removal efforts, and flooded areas are suitable habitat for bullfrogs where NPS never observed breeding

${ }^{\mathrm{b}} \mathrm{A}$ "Yes" denotes the detection of bullfrog DNA in at least 1 of the samples collected

${ }^{\mathrm{c}}$ Total min. surveyed is the combined survey duration of all observers minus any breaks taken 
(Thermo Fisher Scientific). We used the same collection, filtration, storage, and DNA extraction method described in Kamoroff and Goldberg (2018). To determine if bullfrog DNA was present in the samples collected, we analyzed the extracted DNA from the filtered water samples in triplicate using a quantitative polymerase chain reaction (qPCR) and a previously published American bullfrog qPCR assay (Strickler et al. 2015). We included an exogenous internal positive control to ensure no PCR inhibition had occurred (IPC; Applied Biosystems) and that DNA would indeed amplify if it were present in a sample. We ran inhibited samples though OneStep ${ }^{\text {tm }}$ PCR Inhibitor Removal spin columns (Zymo Research). If inhibition was still present, we diluted the samples $1: 10$ and re-analyzed. We created and analyzed negative extraction and qPCR controls with every batch and plate.

We considered the species to have been detected in a sample if all 3 qPCR reaction replicates tested positive. If 1 or 2 of the technical replicates tested positive, we reanalyzed the samples in triplicate. We confirmed the presence of DNA if any reanalyzed replicates tested positive during the 2 nd round. We stored samples at $4{ }^{\circ} \mathrm{C}$ between qPCR runs to minimize DNA degradation caused by heat or multiple freeze-thaw events. We considered a technical replicate to be positive if an exponential increase occurred at any point of the 50 cycles (as described by Goldberg et al. 2013, see also Ellison et al. 2006).

Additional survey methods included the installation of song meters at known bullfrog sites in the Valley. From 2016 to 2018 we deployed 1 song meter at $1-2$ locations where we had previously detected bullfrogs via eDNA surveys. The NPS set the song meters in early spring (April-June) during bullfrog breeding and retrieved them late summer (August-September).

The focus of the removal efforts was to directly manage for non-native species. The project was not set up as a research experiment, rather effort and time was spent when resources were available. Over the past $\sim 15$ years, the project has been managed by different personnel. All project managers had the same goal for removal/eradication of non-native bullfrogs, however methods, efforts, and protocols fluctuated. As a result, we did not conduct visual surveys or eDNA surveys in a systematic approach that would allow for the determination of detection probability of either method.

\section{Results}

We found bullfrog breeding at 6 locations, 5 natural waterbodies and 1 manmade pond, the Ahwahnee Hotel (Fig. 1). Additionally, we found $>15$ flooded areas within Yosemite Valley that we characterized as potential bullfrog habitat (Fig. 1). From 2005 to 2018, we concentrated surveys and removal efforts at those breeding and flooded areas. Available data of individuals removed are likely low estimates (i.e. not all bullfrogs removed were recorded; Fig. 2).

Of the recorded 8126 individuals removed (44 egg masses, 7462 larvae, 67 sub-adults, and 553 adults), the NPS removed $86 \%$ in the first year of concerted effort (2005). When specified, the majority of the bullfrogs removed were from breeding locations $(98 \%$ of specified locations; Fig. 2). The subsequent decade was primarily spent searching for individuals with lower return on effort (Fig. 2). We removed the last observed bullfrog egg mass in 2012 and last observed larvae in 2013; since then, the NPS has not seen signs of bullfrog breeding. We captured two adult bullfrogs in 2014 and another two adult bullfrogs in 2015. In 2016, Valley residents (non NPS staff) reported observing two adult bullfrogs in the Merced River (non-breeding location). We were unable to capture the two frogs reported by residents in 2016, and we did not detected any other bullfrogs at the Merced River site or any other site in the Valley during visual surveys or on song meters from 2015 to 2018. In 2019, we located and captured one male bullfrog that was heard calling by an off duty NPS ranger.

We collected eDNA samples from 4 bullfrog breeding sites in 2015, 11 breeding sites and slack water areas in 2016, and 6 breeding and slack water areas in 2018. We conducted visual surveys at 7, 3, 1, and 8 breeding and slack water area in 2015, 2016, 2017, and 2018 respectively. We focused survey efforts on bullfrog "hotspots" or, later in the project, where we previously detected bullfrog DNA. We detected bullfrog DNA at 3 of 4 sites in 2015, 2 of 10 sites in 2016, and 1 of 6 sites in 2018 (Table 2). We did not observe bullfrogs in any areas where we detected bullfrog DNA, but DNA detects were in areas of previously known bullfrog breeding or occupied sites. We did not detect bullfrog DNA at 1 site where we observed bullfrogs in 2015 (Table 2). We collected eDNA 1 month prior to the bullfrog observations at the site. All eDNA negative control samples, 


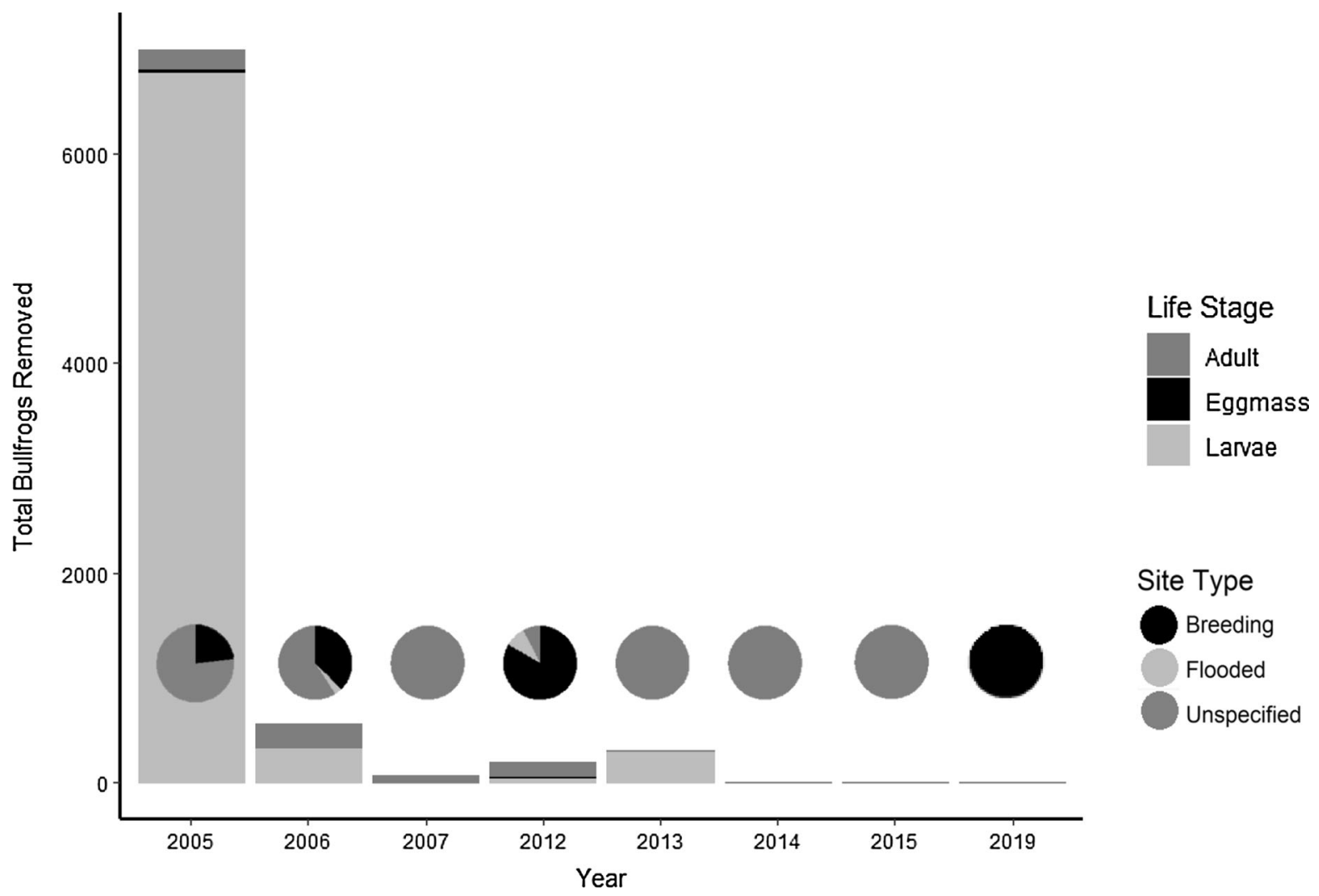

Fig. 2 Bar graph depicts the number American bullfrogs removed in Yosemite Valley from 2005 to 2019 (available numbers of individuals removed are likely low estimates due to limited data collected and recorded throughout the legacy of the bullfrog removal effort). We included all animals removed between 2008 and 2012 in the 2012 column as number of individuals removed was not differentiated per year at this time. Bullfrogs removed are split up by life stage: adult, larvae

extraction negatives, and qPCR negatives tested negative. We treated 4 samples for inhibition.

\section{Discussion}

This is the first peer reviewed journal documenting successful eradication of bullfrogs on a landscape level. Previous studies have been successful in removing bullfrogs from isolated ponds (Orchard 2011), minimizing population size (Ficetola et al. 2007; Orchard 2011), or removing bullfrogs in areas with few individuals (D'Amore et al. 2009). We effectively removed over 8000 individual bullfrogs from 6 breeding sites and $>15$ flooded areas throughout Yosemite Valley, an area of $\sim 1500$ ha. In a (characterized by having a tail), and egg mass. Corresponding pie charts are the percentage of animals removed from each site type from 2005 to 2019. Site types include: breeding (areas where egg masses or larvae were observed), flooded areas (potential bullfrog habitat), and unspecified (unknown or other locations). Figure created in $\mathrm{R}$ version 3.3.0 ( $\mathrm{R}$ Core Team 2016)

review of bullfrog management efforts, Adams and Pearl (2007) explained that there are few practical control methods for bullfrogs. Our work highlights that the removal of bullfrogs in a confined area is possible by targeting breeding populations, using a variety of mechanical removal methods, and monitoring via traditional (visual surveys and audio recording devices) and eDNA survey techniques. Additional factors such as limited sites $(n=6)$ that supported bullfrog breeding and limited time when temperatures and conditions are conducive for breeding due to the Valley's elevational gradient (900-1280 m; Sepulveda and Layhee 2015), contributed to the successful removal of bullfrogs in Yosemite National Park's Valley. 
Our eDNA surveys were sensitive to low densities of individuals, a critical component to invasive species management. From 2015 to 2018, we detected bullfrogs using eDNA methods but did not detect bullfrogs using traditional visual surveys. We even detected bullfrog DNA at Mirror Lake in 2016, a site where we have never observed bullfrogs during visual surveys nor have we observed any evidence of bullfrog breeding. While it is possible that this detection was from exogenous DNA deposited by a predator (e.g., Merkes et al. 2014), the consistent detection indicates bullfrogs have not been eradicated from the area or bullfrogs could be migrating upstream from downstream sources during low-water years. In 2016, Valley residents observed two adult bullfrogs that were never caught, and in 2019, after 4 years of nondetects via visual surveys, NPS found and removed one male bullfrog. The eDNA surveys consistently detected bullfrogs in the valley while it took 4 years of survey effort to find an individual bullfrog via visual surveys. In 2015, we observed 2 bullfrogs in an area we collected eDNA samples 1 month prior. We did not detect bullfrog DNA in the samples indicating that the bullfrogs were either not present at the time of sampling or that our sampling methods failed to detect bullfrog occupancy. At the site, we filtered $200 \mathrm{ml}$ of water (Table 2). Increasing eDNA sample volume, number of samples collected, as well as frequency of sample collection would increase detection and confidence in negative sample results. Using similar methods, Goldberg et al. (2018) found an average persample detection rate of 0.75 . We are unsure the detection probability for bullfrog eDNA in this study as we did not conduct systematic visual surveys and eDNA surveys. However, the consistent detection of bullfrog eDNA and the absence of observations of bullfrog post-2015 suggest that eDNA methods are capable of detecting bullfrogs at very low densities, and eDNA methods are more sensitive to traditional visual surveys.

Our results are consistent with previous findings that eDNA survey methods surpass traditional bullfrog surveys in terms of sensitively (Dejean et al. 2012; Goldberg et al. 2018). Sensitive survey techniques are essential to prevent re-colonization of alien invasive species and particularly bullfrogs, as they are incredibly fecund and can become quickly (re-)established in novel habitats. The use of eDNA to detect invasive species at low density is a promising tool for land managers (Darling and Mahon 2011; Kamoroff and Goldberg 2018). The consistent detection of bullfrog eDNA indicates that low densities of bullfrogs are still be present in the Valley or that bullfrogs may migrate upstream from downstream locations during low water years (Sepulveda and Layhee 2015), therefore, the NPS will continue monitoring the Valley using visual surveys and eDNA techniques in order to catch any new or remaining individuals and prevent re-establishment. However, we have not observed bullfrog breeding since 2012 suggesting that there are not enough individuals to support a population in Yosemite Valley.

After bullfrog removal, the NPS began restoration projects to support California species of special concern. Beginning in 2016, the NPS took action to introduce California red-legged frogs (Rana draytonii; hence red-legged frog) into the Valley. Invasive bullfrogs are one of the main threats to red-legged frogs (Lawler et al. 1999; D'Amore et al. 2009), a federally threatened species endemic to California and in decline across most of its range (U.S. Fish and Wildlife Service 2002). The park captively reared redlegged frog egg masses at the San Francisco Zoo, a program funded by the Yosemite Conservancy. The captive rearing program was extremely successful, and the NPS released approximately 400 adult redlegged frogs into the Valley from 2016 to 2018. During the 2018 fall surveys, the park staff observed the first gravid red-legged frogs, and spring 2019, we observed red-legged frog egg masses at multiple locations. The observation of multiple red-legged frog egg clutches is a promising sign for a successful introduction program.

National Parks and Monuments often provide refuges for imperiled wildlife and should be managed to remove invasive species. The presence of nonnative species, like bullfrogs, can inhibit or completely suppress native herpetofuana and other wildlife. Furthermore, climate change is likely to result in conditions that will favor increased spread of bullfrog invasion (Loyola et al. 2012), underscoring the importance of eradicating bullfrogs in a timely fashion. Our work highlights that effective bullfrog removal is obtainable in contained circumstances and can lead to local recovery of endangered species.

Acknowledgements This work is dedicated to Steve C. Thompson who conceived the idea and initiated the first 
bullfrog eradication effort in Yosemite National Park. Thompson's tireless work and "can-do" attitude help mold Yosemite Valley into a refuge for native aquatic wildlife. Funding for the California red-legged frog restoration project came from the Yosemite Conservancy. Lastly, we thank the park's aquatic seasonal staff who worked long nights removing bullfrogs from the Valley.

Open Access This article is distributed under the terms of the Creative Commons Attribution 4.0 International License (http:// creativecommons.org/licenses/by/4.0/), which permits unrestricted use, distribution, and reproduction in any medium, provided you give appropriate credit to the original author(s) and the source, provide a link to the Creative Commons license, and indicate if changes were made.

Authors' contribution CK led the writing of manuscript, collected and analyzed eDNA aquatic samples, and contributed to field work. ND, RG, TE, and RR contributed to writing of the manuscript, compiling of data, and overseeing field work as well as obtaining funding and resources for project. CG oversaw the processing and analysis of all eDNA samples and contributed to manuscript writing. All authors contributed critically to the drafts and gave final approval for publication.

\section{References}

Adams MJ, Pearl CA (2007) Problems and opportunities managing invasive bullfrogs: is there any hope? In: Gheradi $\mathrm{F}$ (ed) Biological invaders in inland waters: profiles, distribution, and threats. Springer, Dordrecht, pp 679-693

Bai C, Garner TW, Li Y (2010) First evidence of Batrachochytrium dendrobatidis in China: discovery of chytridiomycosis in introduced American bullfrogs and native amphibians in the Yunnan Province, China. EcoHealth 7(1):127-134

Bucciarelli GM, Blaustein AR, Garcia TS, Kats LB (2014) Invasion complexities: the diverse impacts of nonnative species on amphibians. Copeia 4:611-632

Bury RB, Whelan JA (1985) Ecology and management of the bullfrog, vol. 155, US Deparment of the INterior, Fish and Wildlife Service

Cunningham JD (1960) Additions to the vertebrate fauna of Yosemite. Yosemite nature notes XXXIX(3)

D’Amore A, Kirby E, McNicholas M (2009) Invasive species shifts ontogenetic resource partitioning and microhabitat use of a threatened native amphibian. Aquat Conserv Mar Freshw Ecosyst 19:534-541

Da Silva ET, Ribeiro Filho OP, Feio RN (2011) Predation of native anurans by invasive bullfrogs in southeastern Brazil: spatial variation and effect of microhabitat use by prey. S Am J Herpetol 6(1):1-11

Darling JA, Mahon AR (2011) From molecules to management: adopting DNA-based methods for monitoring biological invasions in aquatic environments. Environ Res 111:978-988
Dejean T, Valentini A, Miquel C, Taberlet P, Bellemain E, Miaud C (2012) Improved detection of an alien invasive species through environmental DNA barcoding: the example of the American bullfrog Lithobates catesbeianus. J Appl Ecol 49(4):953-959

Drost CA, Fellers GM (1996) Collapse of a regional frog fauna in the Yosemite area of the California Sierra Nevada, USA. Conserv Biol 10(2):414-425

Dudgeon D, Arthington AH, Gessner MO, Kawabata ZI, Knowler DJ, Lévêque C, Naiman RJ, Prieur-Richard AH, Soto D, Stiassny MLJ, Sullivan CA (2006) Freshwater biodiversity: importance, threats, status and conservation challenges. Biol Rev Cambridge Philos Soc 81:163-182

Dunker KJ, Sepulveda AJ, Massengill RL, Olsen JB, Russ OL, Wenburg JK, Antonovich A (2016) Potential of environmental DNA to evaluate Northern Pike (Esox lucius) eradication efforts: an experimental test and case study. PLoS ONE 11(9):e0162277

Ellison SLR, English CA, Burns MJ, Keer JT (2006) Routes to improving the reliability of low level DNA analysis using real-time PCR. BMC Biotechnol 6:33

Emlen ST (1977) "Double clutching" and its possible significance in the bullfrog. Copeia 25(4):749-751

Ficetola GF, Thuiller W, Miaud C (2007) Prediction and validation of the potential global distribution of a problematic alien invasive species-the American bullfrog. Divers Distrib 13(4):476-485

Ficetola GF, Maiorano L, Falcucci A, Dendoncker N, Boitani L, Padoa-Schioppa EM, Miaud C, Thuiller W (2010) Knowing the past to predict the future: land-use change and the distribution of invasive bullfrogs. Glob Change Biol 16(2):528-537

Fuller TE, Pope KL, Ashton DT, Welsh HH Jr (2011) Linking the distribution of an invasive amphibian (Rana catesbeiana) to habitat conditions in a managed river system in northern California. Restor Ecol 19(201):204-213

Goldberg CS, Sepulveda A, Ray A, Baumgardt J, Waits LP (2013) Environmental DNA as a new method for early detection of New Zealand mudsnails (Potamopyrgus antipodarum). Freshw Sci 32:792-800

Goldberg CS, Strickler KM, Fremier AK (2018) Degradation and dispersion limit environmental DNA detection of rare amphibians in wetlands: increasing efficacy of sampling designs. Sci Total Environ 633:695-703

Kamoroff C, Goldberg CS (2018) An issue of life or death: using eDNA to detect viable individuals in wilderness restoration. Freshw Sci 37(3):685-696

Kupferberg SJ (1997) Bullfrog (Rana catesbeiana) invasion of a California river: the role of larval competition. Ecology 78(6):1736-1751

Lawler SP, Dritz D, Strange T, Holyoak M (1999) Effects of introduced mosquitofish and bullfrogs on the threatened California red-legged frog. Conserv Biol 13(3):613-622

Li Y, Ke Z, Wang Y, Blackburn TM (2011) Frog community responses to recent American bullfrog invasions. Curr Zool 57(1):83-92

Lowe S, Browne M, Boudjelas S, De Poorter M (2000) 100 of the world's worse invasive alien species a selection from the global invasive species database. Invasive Species Specialist Group, Auckland 
Loyola RD, Nabout JC, Trindade Filho J, Lemes P, Cardona JN, Dobrovolski R, Sagnori MD, Diniz Filho JA (2012) Climate change might drive species into reserves: a case study of the American bullfrog in the Atlantic Forest Biodiversity Hotspot. Alytes 29(1-4):61-74

Luja VH, Rodríguez-Estrella R (2010) The invasive bullfrog Lithobates catesbeianus in oases of Baja California Sur, Mexico: potential effects in a fragile ecosystem. Biol Invasions 12(9):2979-2983

Merkes CM, McCalla SG, Jensen NR, Gaikowski MP, Amberg JJ (2014) Persistence of DNA in carcasses, slime and avian feces may affect interpretation of environmental DNA data. PLoS ONE 9(11):e113346

Moyle PB (1973) Effects of introduced bullfrogs, Rana catesbeiana, on the native frogs of the San Joaquin Valley, California. Copeia 1973:18-22

Orchard SA (2011) Removal of the American bullfrog, Rana (Lithobates) catesbeiana, from a pond and a lake on Vancouver Island, British Columbia, Canada. In: Island invasives: eradication and management. IUCN, Gland, Switzerland, pp 1-542

Rahel FJ, Bierwagen B, Taniguchi Y (2008) Managing aquatic species of conservation concern in the face of climate change and invasive species. Conserv Biol 22(3):551-561

R Core Team (2016) R: A language and environment for statistical computing. R Foundation for Statistical Computing, Vienna, Austria. https://www.R-project.org/

Rees HC, Maddison BC, Middleditch DJ, Patmore JRM, Gough KC (2014) The detection of aquatic animal species using environmental DNA- a review of eDNA as a survey tool in ecology. J Appl Ecol 51:1450-1459

Schloegel LM, Ferreira CM, James TY, Hipolito M, Longcore JE, Hyatt AD, Yabsley M, Martins AM, Mazzoni R, Davies AJ, Daszak P (2010) The North American bullfrog as a reservoir for the spread of Batrachochytrium dendrobatidis in Brazil. Anim Conserv 13:53-61

Sepulveda AJ, Layhee M (2015) Description of fall and winter movements of the introduced American Bullfrog (Lithobates catesbeianus) in a Montana, USA, pond. Herpetol Conserv Biol 10(3):978-984

Strickler KM, Fremier AK, Goldberg CS (2015) Quantifying effects of UV-B, temperature, and $\mathrm{pH}$ on eDNA degradation in aquatic microcosms. Biol Conserv 183:85-92

Taberlet P, Coissac E, Hajibabaei M, Riesenberg LH (2012) Environmental DNA. Mol Ecol 21:1789-1793

Underwood W, Anthony R, Cartner S, Corey D, Grandin T, Greenacre CB, Gwaltney-Bran S, McCrackin MA, Meyer R, Miller D (2013) AVMA guidelines for the euthanasia of animals, 2013th edn. American Veterinary Medical Association, Schaumburg

U.S Fish and Wildlife service (2002) Recovery plan for the California red-legged frog (Rana aurora dryatonii). U.S. Fish and Wildlife Service, Portland, Oregon

Yosemite National Park (2019) Unpublished data

Publisher's Note Springer Nature remains neutral with regard to jurisdictional claims in published maps and institutional affiliations. 